\title{
Estimation of Annual Erosion in Six Soil Series of the Federal University of Agriculture Abeokuta Nigeria using Rusle in Map Algebra
}

\section{${ }^{* 1}$ OYEDEPO, JA; ${ }^{2}$ OLAWALE, RA; ${ }^{1}$ OLUYEGE, DE; ${ }^{1}$ BABAJIDE, EI}

\author{
${ }^{1}$ Institute of Food Security, Environmental Resources and Agricultural Resources (IFSERAR) \\ ${ }^{2}$ College of Environmental Resources Management \\ Federal University of Agriculture, Abeokuta Nigeria \\ *Correspondence: johnoyedepo@gmail.com
}

\begin{abstract}
Anthropogenic activities such as deforestation, bush burning and extensive opening of farmlands in the 10,000 hectares at the Federal University of Agriculture, Abeokuta (FUNAAB) have increased vulnerabilities of the seven soil series in the campus to agents of erosion. Therefore it is important to evaluate the rate and locations of soil erosion in the study area inorder to develop erosion control intervention programme using standard methods. The results show that overall soil erosion ranges from 0 to 167.8 tons per hectare per annum. $10 \%$ of University land now has high risk of soil erosion being grasslands exposed to annual fires. Soil erosion is pronounced in the two soil series (Oke-imesi and Apomu) that are found along river fringes with topographic factors (Slope length and steepness) playing major role in the soil erosion
\end{abstract}

DOI: https://dx.doi.org/10.4314/jasem.v24i10.7

Copyright: Copyright (C) 2020 Oyedpo et al. This is an open access article distributed under the Creative Commons Attribution License (CCL), which permits unrestricted use, distribution, and reproduction in any medium, provided the original work is properly cited.

Dates: Received: 15 August 2020; Revised: 22 September 2020; Accepted: 19 October 2020

Keywords: Soil series; Erosion; Map algebra; Spatial model

The soil is described as a multifunctional and nonrenewable environmental resource (Várallyai, 2015; Lal, 2015; Cooke, 2020). It may become lost irretrievably where proper evaluation and management practices are missing (Sharda, et al., 2002, Walin, 2013). The annual loss of productive soil is therefore not inconsistent with sustainable agriculture (AfDB, 2013). As such, for an African country like Nigeria, maximum soil conservation Various aspects of the soil of attributes have been documented at the University of Agriculture, Abeokuta Nigeria (Ajiboye, et al., 2011; Ajiboye and Aduloju, 2013; Ajiboye, et al., 2014; Ajiboye et al., 2015a; Abatan, et al., 2016; Alabi, et al., 2017). Soils of the University have been characterized by their series and structures (Aiboni, 2001) and a few studies have also been conducted to examine rainfall erosivity and rainfall kinetic energy of the Soils (Salako et al., 2006b; Salako, 2007; Salako, 2008; Salako et al., 2008). Changes in morphogenetic and physicochemical properties of an Alfisol in charcoal production area were also recently examined (Ajiboye, et al., 2019). Notwithstanding, only a few efforts have rested on the prediction of annual soil loss of the entire campus and where such studies existed, the geographical scope of the study has been narrowed to manageable land areas. Meanwhile, continuous cropping of the University land from year to year was found to be leading to fertility loss (Dada, et al., 2016). This aligns with the assertion that constant tillage operations increase porosity and macro-porosity in soils (Veiga et al., 2008). This also reduces soil bulk density and consequently increasing the vulnerability of soils to erosion (Tavares and Tessier, 2009). The University land mass is comprised of six soil series of which is imperative to calculate the rate their erosion and the precise locations to direct soil conservation and management practices.

Theoretical Underpinning: Wischmeier and Smith (1978) developed an equation to determine soil erosion of an area by combining five factors that contributes to soil erosion in a simple algebraic model. All of the five factors are multiplied together as in the equation below:

$$
A=R \times K \times L S \times C M \times P
$$

A is amount of soil lost to erosion in a year (tons/ha), $\mathrm{R}$ is the erosivity of rainfall (accounting for the erosive power of rainfall), $\mathrm{K}$ is the soil erodibility (tons/ha) of given soils" (Barrena-González et al., 2020). Soil erodibility values differ from soil to soil $(<0.1$ to 1.0$)$. "The LS represents the length and steepness of the slope" (Vijith et al., 2018); "longer slopes produce larger run-off volume while steeper slopes produce higher run-off velocities" (Ghosh and Guchhait, 2012). This is significant in the removal of large quantities of 
soil particles. C is soil cover factor which accounts for the "protective effects natural vegetation and crop, including their leaf litter and residues" (Kassam et al., 1993). $\mathrm{P}$ is factor for physical protection of soil from erosion (particularly accounting for the effects of soil conservation measures). The first equation was revised by separating the two elements of "the cover and management factor to give the Revised Universal Soil Loss Equation (RUSLE)" (Morgan and Nearing, 2016) as follows:

$$
\text { : } A=R \times K \times L S \times C \times P \ldots \ldots \ldots \ldots \text { (2) }
$$

Soil-erodibility determination in nomograph (Wischmeier and Smith, 1978): Direct measurements taken on plots with natural runoffs have been argued as best way to obtain soil-erodibility (Cassol et al., 2018). Simulation of rainfall on plots and predictive relationships are other ways of obtaining soil erodibility, but these methods have been proved to be less accurate (Renard et al., 1997).

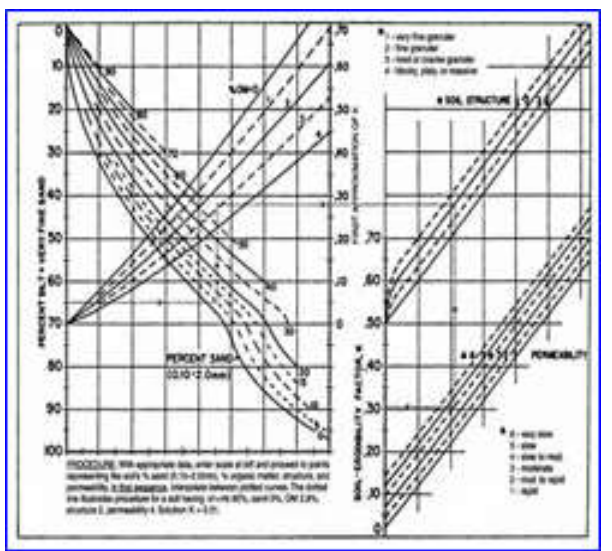

Fig. 1. The nomograph for soil-erodibility (adapted from Wischmeier and Smith, 1978)

Many and varied properties of the soil (physical, chemical, mineralogical) and their interactions affect erodibility (K-factor) values. To accurately describe erodibility values for each soil series, more soil characteristics will be needed. In the several past studies attempts at measuring soil-erodibility $(\mathrm{K})$ values have referenced the nomographs (Arab et al., 2013; Addis and Klik, 2015). The figure below is the nomograph for five soil parameters namely: "percent modified silt ( 0.002 to $0.1 \mathrm{~mm})$, percent modified sand $(0.1$ to $2 \mathrm{~mm})$, percent organic matter $(\mathrm{OM})$, and structural classes (s) and permeability (p)".

$K$ value is in U.S. unit of tons per acre (to convert it to the SI unit, the K values are divided by 7.59)
A useful algebraic approximation of the above nomograph for cases where silt fraction is not more than $70 \%$ is"

$$
\begin{array}{r}
\mathrm{K}=2.1 * 10-4(12-O M) M 1.14+3,25(s-2) \\
+2.5(p-3)] / 100 \ldots \ldots \ldots .(3)
\end{array}
$$

Where $\mathrm{M}$ is the product of the primary particle size fractions:

(\% modified silt or the 0.002

$$
\begin{aligned}
& -0.1 \mathrm{~mm} \text { size fraction }) \\
& *(\% \text { Silt }+\% \text { Sand })
\end{aligned}
$$

$\%$ modified silt or the $0.002-$

$0.1 \mathrm{~mm}$ size fraction $) *(\%$ Silt $+\%$ Sand $)$

To supply values that will fit into the above expressions, it was necessary to carry out particle size analysis, permeability test as well as Organic matter content determination.

Erodibility ( $k$ factor): The erodibility is measured on a scale from 0 to 1 for any soil type. The values 0 is for soils with the least predisposition to erosion, while the value of 1 , refers to soils that are highly susceptible to water erosion.

Description of study area: The University of Agriculture, is situated on a 9,800 ha of land between latitudes $7^{\circ} 13^{\prime} 30^{\prime} \mathrm{N}$ and $7^{\circ} 19^{\prime} 00^{\prime \prime} \mathrm{N}$ and longitudes $3^{0} 20^{\prime} 15^{\prime \prime} \mathrm{E}$ and $3^{\circ} 27^{\prime} 30^{\prime \prime}$ E. along Alabata Road in Abeokuta southwest Nigeria. The landmass generally described as Lixisol by the Harmonized World Soil Database (HWSD, 2009) is further disaggregated into seven soil series namely: Apomu, Egbeda, Ekiti, Iseyin, Iwo, Jago and Oke-Imesi. The area forms part of the transition zone between the humid lowland rain forest of Nigeria and its southern guinea savanna agroecological zone (Adepoju et al., 2019). It is described in the literature as derived savanna (Oyenuga, 1967; Greig-Smith, 1991; Omokhafe, 2017). The vegetation comprises of a mixture of secondary forest regrowth of smooth-barked trees and scaly barked savanna trees with sub-dominant grasses. The general land use is both intensive and extensive rain-fed agriculture. 


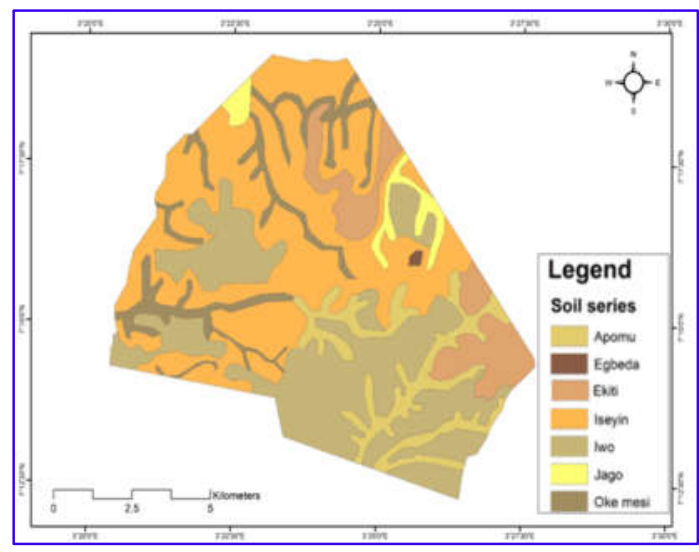

Fig. 2. The map of the FUNAAB boundaries showing the seven soil series

The land area is drained by a network of tortuous rivulets ramifying the landscape and all draining into the Ogun River in the northern and eastern portions of the campus area. The climate is tropical with wet season commencing in March and ending in October, while the dry seasons begin in November and ending in February. Rainfall distribution graph is bimodal; the first peak is in July and the second is in September. There is a short break in rainfall in August. Average annual rainfall is $1113.1 \mathrm{~mm}$. Rainfall is sometimes intense with lightning and thunderstorm at the beginning and end of the season (Ufoegbune and Fabiyi, 2016). Average monthly temperature of the area is between $22.9^{\circ} \mathrm{C}$ to $36.32^{\circ} \mathrm{C}$.

Data type and acquisition: The study relied on data from both primary and secondary sources including data obtained from previous studies and satellitederived remote sensing data. The data from the primary source are mainly the representative soil samples obtained in replicates from each soil series. Data from secondary sources include: Rainfall intensity distribution was derived from the Climate Hazards InfraRed Precipitation Station (CHIRPS) data. Digital Elevation Models (DEM) data obtained from the Shuttle Radar Topographic Mission (SRTM) was subjected to spatial analysis to derive slope length and steepness (Karan et al., 2019). The soil series map was retrieved from the archive of the University Physical Planning Unit (PPU). The PPU archive also contains the baseline data in the original master plan of the University. The Land use and Land cover (LULC) types (Dastagir, et al., 2020) was produced from supervised classification (Bewket and Teferi, 2009) of Landsat TM image of the University.
Soil Sample collection and analysis: Undisturbed samples were collected (using Core sampler's method) from "two depths $(0-15 \mathrm{~cm}$ and $15-30 \mathrm{~cm})$ in each of the six soil series". The geographic coordinates of soil sample locations were obtained with the aid of a handheld GPS receiver.

Method for producing annual soil loss map: The algebraic functions in GIS were deployed in producing a composite map of annual soil loss. A set of algebraic operations in a GIS permits two or more raster layers ('map') of similar dimensions to produce a new raster layer (map) using the multiplication or other operators such as additions, subtraction, and division in the raster calculator.

Rasterization of maps and soil loss parameters: The hard copy map of the seven soil series in FUNAAB namely Jago, Apomu, Iseyin, Ekiti, Egbeda, Iwo, and Oke-Imesi (Ufoegbune and Fabiyi, 2016) was georeferenced, digitized ('heads-up'), and converted to the grid using 0.0028 as grid cell size. Each grid cell was assigned a uniform value of 1 . The soil the series map was however symbolized (using unique ID numbers 1 to 7 ) to distinguish the boundaries of each

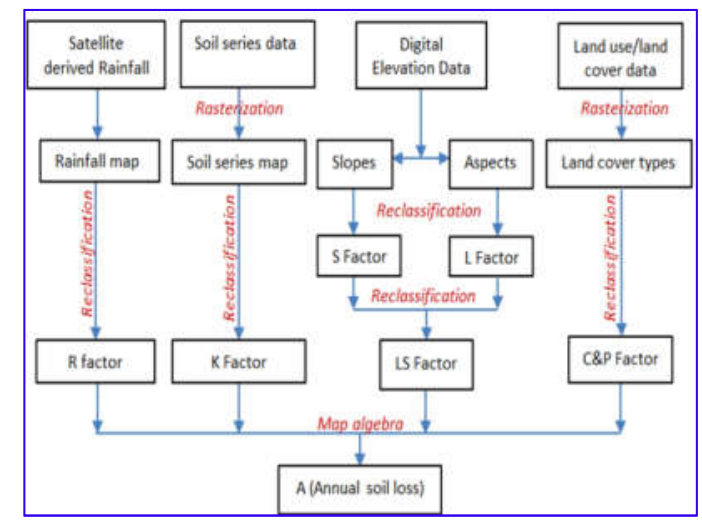

soil series as shown in figure 1 .

Fig. 3. Flow chart diagram showing the steps followed for the

annual soil loss map

Maps of RUSLE Components: All factors of soil erosion in the RUSLE (equation 2) are prepared as a grid map with the same grid cell size. With the grid map of all soil loss factors prepared on the same scale and cell size, map algebra was then easy, using the multiplication operator in the map calculator. Each component of the soil loss namely "erosivity" (R), "erodibility" (K), "slope length" (L, S), "conservation practice" (C), and "physical protection" factor (P) were expressed in raster map format. The same grid cell size used for the soil series map was used for all 
RUSLE component maps. This allowed for alignment and easy overlay operations. The procedures for producing the map for each soil, loss factor are presented in figure 3

Total erosivity of rain ( $R$ factor): Annual Rainfall data obtained from the CHIRPS (covering 2009 to 2018) were imported into a GIS environment. The raster calculator was used to obtain the total rainfall in the 11 year period. The average values for the period was then computed by dividing the total with 11 using the Spatial Analyst raster calculator in ArcGIS. The equation below is the mathematical model for "rainfall erosivity" (Lee and Lee, 2006):

$$
R=38.5+0.35 * P r
$$

Here, "Pr is the annual average rainfall/number (Ganasri and Ramesh, 2016) of years (mm/yr)" as shown in figure 3 . The computed $\mathrm{R}$ from the equation above was transformed to rainfall intensity map.

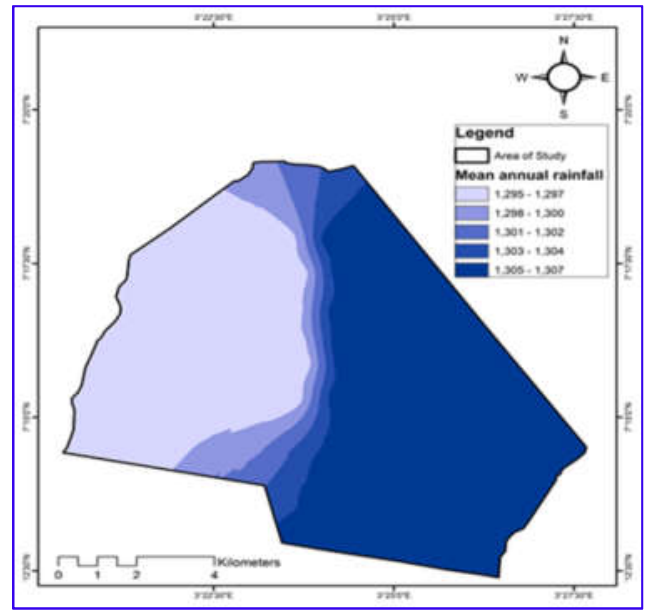

Fig. 4. Rainfall intensity variability distribution across FUNAAB campus area

Erodibility ( $k$ factor): The respective $\mathrm{K}$ values for each soil series from laboratory experiments and reference to nomograph was translated into a raster map. Each soil series (with uniform cell value of 1) was multiplied by the respective soil-erodibility values earlier calculated.

Topographic factor ("Slope length and steepness- $L S$ "): "The effect of length and steepness of slope on soil erosion" (Angima, et al., 2003) (LS factor) was computed from a $30 \mathrm{~m}$ resolution DEM data derived from the SRTM data. Two major factors were combined to calculate the length of the slope, which include: the slope degree and the flow accumulation. The DEM was used to calculate the slope degree and also flow accumulation using ArcGIS spatial analyst extension.

The flow accumulation and slope degree were combined with equation 4 below using the raster calculator in ArcGIS" (Bewket and Teferi, 2009).

$$
L S=\left(F A \times \text { Cell } \frac{\text { size }}{22.1}\right) 0.4 \times\left(\sin \left(\frac{\text { slope } \times 0.01745}{0.09}\right) 1.4\right.
$$

Where $\mathrm{FA}=$ flow accumulation.

The outcome is presented in figure 9 as a map with same cell size and parameters as previous maps.

Cover and Management factors (C\&M): Each land cover types were reclassified (as shown in figure 54) to produce the cover $(\mathrm{C})$ factor map, [Lee and Lee, 2006; Ganasri and Ramesh, 2016).

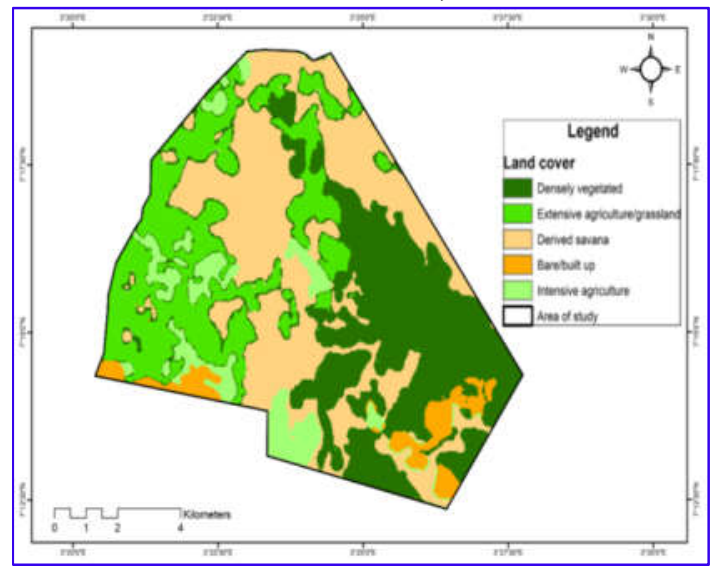

Fig. 5. Land use / land cover categories of FUNAAB

Supervised classification of 2018 Landsat imagery (using maximum likelihood classifier) produced the five major land use/ land cover classes (Densely vegetated, Extensive agriculture, Intensive agriculture, Derived Savanna and Bare-land /built-up environment) were produced as shown in figure 5

Overall annual soil loss: Overall erosion map of the University (see figure 10) was produced by multiplying the raster maps of erosivity by the map of erodibility by the map of conservation practice/management and by the map of slope length and steepness. The annual soil was therefore obtained as a single map showing five distinct class ranges with 
the least as $0-16\left(\mathrm{t}^{-1} \mathrm{Ha}^{-1} \mathrm{yr}^{-1}\right)$. The largest erosion range in the University is $98-203\left(\mathrm{t}^{-1} \mathrm{Ha}^{-1} \mathrm{yr}^{-1}\right)$. The map appears to depict that, the University does not have serious issues with soil loss yet since not more than $10 \%$ of the 10,000 hectares loses up to 1.6 tons of soil per hectare per year.

\section{EXPERIMENTAL}

Particle size determination: The soil samples from the locations of the 6 major soil series were subjected to particle size analysis (\% fine sand, silt, clay) and organic matter content determination using the hydrometer method (Bouyoucos, 1962).

The values obtained were used to estimate the erodibility ( $\mathrm{k}$ factor). $50 \mathrm{~g}$ of $(2 \mathrm{~mm})$ sieved soil sample was measured into $250 \mathrm{ml}$ conical flasks and $50 \mathrm{ml}$ of sodium hexametaphosphate solution (calgon solution) was added with $100 \mathrm{ml}$ of distilled water. The samples were left overnight to allow the soil to soak properly before mechanical dispersal.

The soil was transferred into a dispersing cup and dispersed using a mechanical stirrer for 5 minutes. The mixture was immediately transferred to $1000 \mathrm{ml}$ measuring cylinder. The dispersing cup was rinsed into the measuring cylinder until there was no trace of soil particle in the cup. Thereafter water was added to fill the $1000 \mathrm{ml}$ cylinders up to $900 \mathrm{ml}$ mark and a soil hydrometer was inserted into the cylinder before adding water to mark. With the mouth covered, the cylinder was inverted several times to ensure that the soil was properly suspended. The dispersed soil was placed on a flat table - top and allowed to rest.

The first hydrometer reading was taken 40seconds after the suspension was set down and temperature was also taken using a thermometer. Both the hydrometer and temperature readings were recorded (first readings). Just before $2 \mathrm{hrs,} \mathrm{the} \mathrm{hydrometer} \mathrm{was}$ inserted again into the soil suspension and the second hydrometer readings were taken again at 2 hours.

The temperature was equally taken. Both the HR and temperature readings were recorded as 2 nd reading. The percentage sand, clay and silt in the soil were calculated using the formula below:

$(\%$ sand $+\%$ silt $+\%$ clay $)=100 \ldots \ldots .(6)$
$\%$ sand $=100-(\%$ silt $+\%$ clay $) \ldots \ldots .(7)$
$\%($ silt + clay $)$

$=100$ (1st reading

+ corrected temp reading) $\mathrm{x} 100$

$\div$ weight of soil...(8)

$\%$ clay

$=+(2 n d$ reading

+ corrected temp reading) $\times 100$

$\div$ weight of soil .....(9)

$\%$ silt $=100-\%($ silt + clay $)-$

(\% clay) .......(10)

Permeability test: The permeability test was conducted using Reynolds constant head soil core method (Basile et al.,, 2020) in line with Darcy equation for vertical flow of liquid. "Saturated Hydraulic Conductivity (Ks) was determined using undisturbed soil samples collected with core samplers at different soil depths" (Ajiboye et al., 2015). A constant water head was maintained on each core sample. The amount of water that passed through the soil in the core at set time was recorded. Saturated hydraulic conductivity (Ks) is given by the equation below:

$$
K s=\frac{Q w \times d}{h \times A \times t} \ldots \ldots \ldots \ldots
$$

Qw is the quantity of water $\left(\mathrm{cm}^{3}\right)$ that flowed through a cross-sectional area $\mathrm{A}\left(\mathrm{cm}^{2}\right)$ in time $(\mathrm{t})$, and $\mathrm{h}$ is the hydraulic head difference $(\mathrm{cm})$ imposed across the sample length d (cm)."

Organic Matter determination: Organic matter was determined from Organic carbon estimation. Air dried soil samples were sieved using $0.5 \mathrm{~mm}$ mesh screen" (Angima et al., 2003). $0.5 \mathrm{~g}$ of the sieved soil was weighed on a sensitive scale balance. The weighed soil was poured into a "conical flask"; then $10 \mathrm{mls}$ of potassium dichromate was added along with concentrated Sulfuric acid. The mixture was swirled and left for half of an hour. " $50 \mathrm{mls}$ of distilled water was then added with five drops of Orthophenatrolein solution as indicator". The solution was then titrated against Ammonium ferrous sulphate solution. The formula below was used in the calculation:

$\% O M=\% O C \times 1.724 N \ldots \ldots .(12)$

Where $\mathrm{OM}=$ organic matter, $\mathrm{OC}=$ organic carbon, $\mathrm{N}$ is Normality of Ferrous sulphate; Normality of Ferrous 
sulphate $=$ volume of $\mathrm{K} 2 \mathrm{CrO} 7$ used for blank/Titre value for blank" (Nath and Krishna, 2014).

\section{RESULTS AND DISCUSSION}

In table 1, the four parameters used to determines soilerodibility namely; soil structure, soil texture, permeability and organic matter are presented. The texture of the soil is determined by the relative percentage composition of sand, silt or clay" (Kusumandari, 2014). Textural analysis of the six series reveals high sand percentage ( 77.94 to $94.95 \%$ ) in the soil series in the University. Clay content ranged from 4.06 to $15.06 \%$ and silt content from 0.99 to $6.99 \%$, respectively. The general implication of these is that most of the soils are highly erodible if they are bare. "Clay-rich soils with a low shrink-swell capacity have low erodibility value, since clay particles mass together and form large aggregates that resist detachment and transport processes unlike sandy soils"
(Kusumandari, 2014). Organic matter content in soils influences its physical and chemical properties by building up aggregation. Normally, soil organic matter affects soil erodibility, infiltration, water detention, and shear strength of soil. The results of soil organic content analysis showed values varying from 0.07 to $3.29 \%$ which can be considered to be moderate; "preventing soil particles from detachment by the kinetic energy of rainfall and providing very low threshold of soil erodibility" (Yusof et al., 2011). The grain size distribution of soil determines the level of ease with which a particular fluid flows through the interconnecting voids of soil. From the nomograph calculations, the relative soil-erodibility values for the soil series is as presented in the table 2 . The values inTable 2 was translated into raster map by multiplying the soil series with their respective erodibility (Kfactor) values to produce the erodibility map as shown in the figure 6

Table 1. The physical and chemical characteristics of the soil series

\begin{tabular}{lllllllll}
\hline LOCATION & SILT & SAND & CLAY & O C & OM & KS & K & SC \\
\hline APOMU & 1.99 & 92.95 & 5.06 & 0.40 & 0.69 & 93.09 & 0.4 & 2 \\
EKITI & 1.99 & 92.95 & 5.06 & 0.84 & 1.44 & 24.25 & 0.1 & 2 \\
ISEYIN & 0.99 & 94.94 & 4.06 & 0.04 & 0.07 & 78.72 & 0.4 & 2 \\
IWO & 0.99 & 94.95 & 4.06 & 0.04 & 0.07 & 22.51 & 0.2 & 2 \\
JAGO & 0.99 & 91.94 & 7.06 & 1.92 & 3.29 & 8.83 & 0.1 & 2 \\
OKEMESI & 6.99 & 77.94 & 15.06 & 0.68 & 1.17 & 28.64 & 0.2 & 2 \\
\hline
\end{tabular}

Table 2. The relative "soil-erodibility values" for the series

\begin{tabular}{llll}
\hline SOIL SERIES & $\begin{array}{l}\text { K-factor } \\
\text { Value (ton.acre }\end{array}$ & $\begin{array}{l}\text { K-factor Value in SI } \\
\text { unit (t.ha.ha }\end{array}$ & Remarks \\
\hline APOMU & 0.04 & 0.0052 & \\
EKITI & 0.05 & 0.0066 & Low \\
ISEYIN & 0.20 & 0.013 & Low \\
IWO & 0.23 & 0.017 & Moderate \\
JAGO & 0.22 & 0.015 & Moderate \\
OKEMESI & 0.21 & 0.014 & Moderate \\
\hline
\end{tabular}

The result shows that soil erodibility in the university is relatively low; with values ranging from 0.04 to 0.23 $\mathrm{t} /$ ha as shown in table 2.

Areas with moderate erodibility in the series have a higher amount of sand than areas with higher silt contents. Areas with low erodibility also have low permeability and higher resistance to particle detachment.

Proper land management and presence of high vegetation cover in the some parts of the university probably contributes to low erodibility. Similarly, the presence of high organic matter increases cohesion of soil particles thereby lowering erodibility. Okemesi and apomu series are moderately rich in clay particles. They are able to form stable aggregates, which makes them less susceptible to erosion than other soil types. These soils are still moderately erodible. Ekiti State falls in areas with minimal anthropogenic activities.

The area occupied by ekiti soil series have not been released by the aborigines, it consist of community sacred grove. The portion covering almost 1,000 ha is reported as the most viable agricultural land in the University. 
Erosivity of Rainfall (R factor): Variability distribution of the erosive power of rainfall is presented in fig 7 .

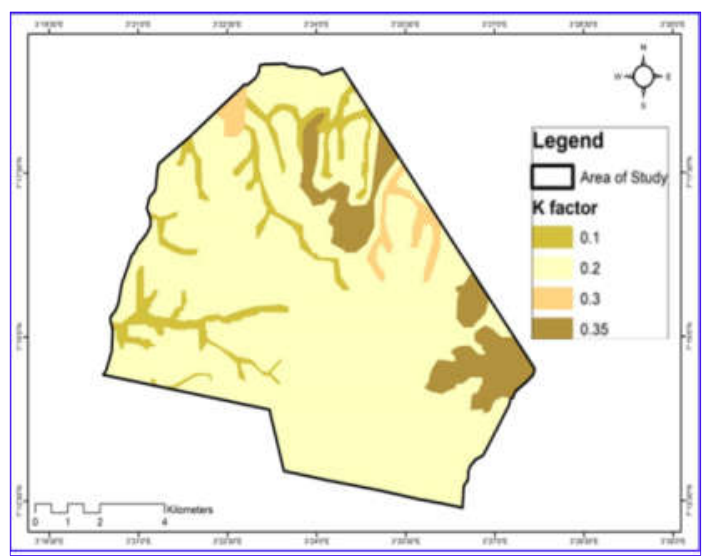

Fig.6. Erodibility distribution across the university

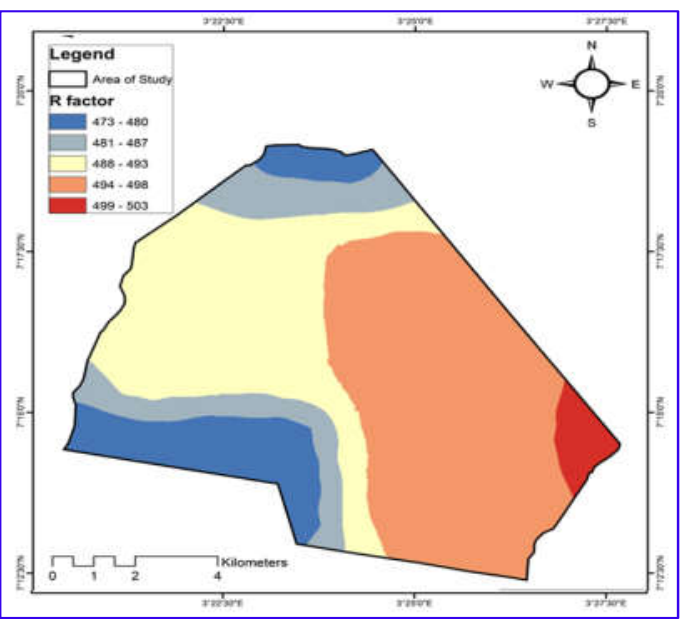

Fig. 7. Erosivity of rainfall (R-factor) across the University land

The detaching power of raindrops and scouring influence of runoffs are important considerations in soil erosion (Morgan et al., 1994).

Land cover and Land management (C\&M) factors: To produce the cover and management ( $\mathrm{C}$-factor) map; which gives the relative influence of "vegetation cover and management practice" (Krasa et al., 2009) on erosion of soil, each land cover types were reclassified as shown in table 3 in line with Lee and Lee, (2006) and Ganasri and Ramesh, (2016).

The values in table 3 is presented as a map in figure 8

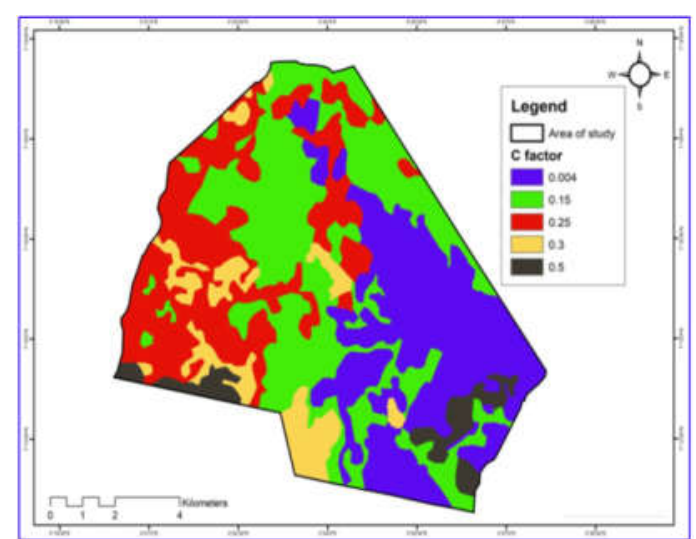

Fig. 8. Cover and management $(C \& M)$ factors in FUNAAB land area

Table 3: Land use types and corresponding C-factor values

\begin{tabular}{ll}
\hline Land Use & C Factor \\
\hline Densely Vegetation & 0.004 \\
Derived Savanna & 0.15 \\
Intensive Agriculture & 0.3 \\
Extensive Agriculture & 0.25 \\
Bare/Built-up lands & 0.5 \\
\hline
\end{tabular}

Topographic factors: The effect of landscape on erosion in soils can be assessed through length and steepness of slope of an area. The potential for soils to be washed away by any agent of erosion increases length and steepness of the slope in that area (Ferreira et al., 2015; Gaubi et al., 2017). In FUNAAB soil series, elevation value ranges from $50 \mathrm{~m}$ to $700 \mathrm{~m}$. Most of parts of the soil series are characterized by low LS factor values which consequently favor low to moderate soil loss. The University land area according to topography (LS factor) can be classified into five as shown on the map in figure 9. About ninety per cent of the University land has LS values of less than 0.02 percent; indicating that imperceptible erosion. Locations where LS values exceed 5 percent are almost inconsequential.

The overall annual erosion map: The RUSLE equation is the product of all factors that contribute to soil erosion, hence the maps in figures 5, 6, 7, 8 and 9 were multiplied in turns to give the overall erosion map in figure 10. The resulting map show that the overall soil erosion ranges from 0 to 167.8 tons per hectare per annum.

The least value ranges between $0-1.3$ tons $\mathrm{ha}^{-1} \mathrm{yr}^{-1}$, 
while the highest range of value is from 87.6 to 167.8 tons $\mathrm{ha}^{-1} \mathrm{yr}^{-1}$. Juxtaposing the map of annual soil loss with that of the soil series helped in identifying locations where potential soil loss is pronounced.

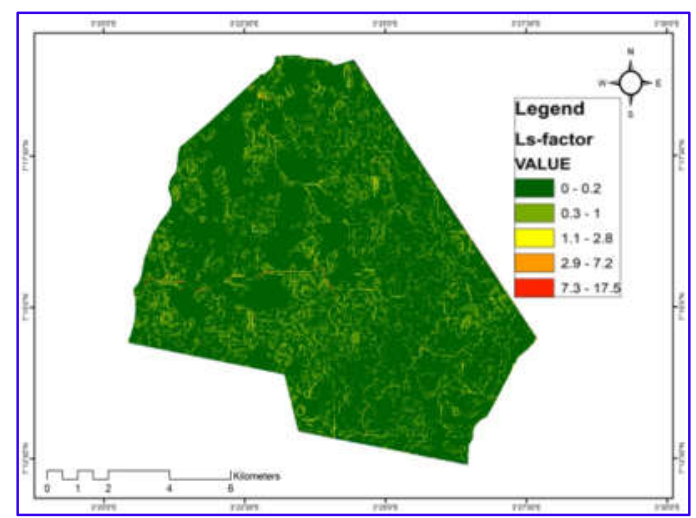

Fig. 9. Topographic factors (LS) of FUNAAB land area

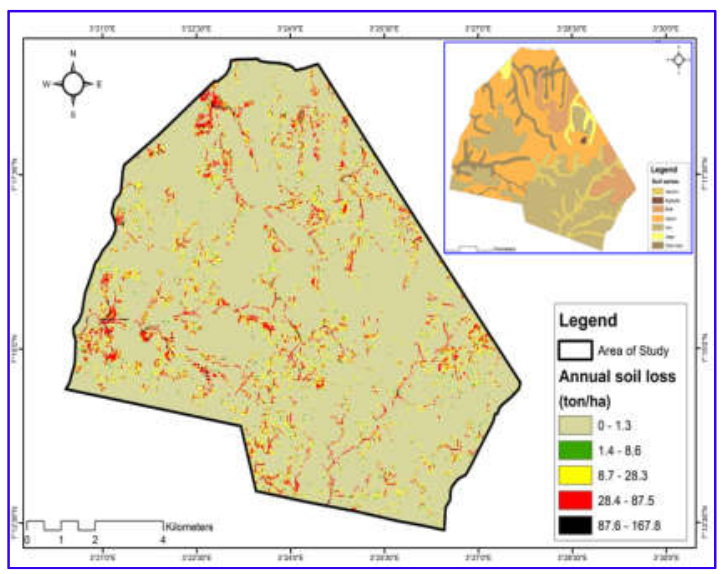

Fig. 10. The map of annual soil loss (Inset:

FUNAAB soil series)

For example, Egbeda, Ekiti, Iseyin and Iwo series does not have serious soil loss problems because of favourable cover and slope factors. This is evident from figure 9 that the location of the four soil series have 0 to 1.3 ton/ha of soil loss. Areas with noticeable soil loss ranging between 28.4 to 87.5 tons /ha (in yellow, red and black colours) include Jago, Oke-imesi and Apomu soil series. Incidentally, these three series are along river fringes; where topography (Slope length) play major role. Locations with potential soil loss above 100 tons per hectare are pockets within these three series. It will also be noticed that the soil series with pronounced erosion are those at the fringes of river banks. Generally, the annual soil loss map does not depict that large portions of the University land have serious issues with soil loss yet. particularly since not more than $10 \%$ of the 10,000 hectares loses up to 1.3 tons of soil per hectare per year

Conclusion: The study reveals variation amongst the soil series with regards to erodibility and other factors of erosion. Topography has the strongest influence on soil loss. Meanwhile, less than $10 \%$ of the 10,000 hectares are vulnerable to erosion; losing up to 1.3 tons of soil per hectare per year. Of the several factors required for soil conservation; proper land management, adequate land cover (vegetation) and good drainage system would be useful in keeping soil loss rate below 10 tons/ha.

\section{REFERENCES}

Abatan, AO, Akinyemi, OD, Olowofela, JA, Ajiboye, GA and Salako, FK (2016). Experimental investigation of factors affecting compressional and shear wave velocities in shale and limestone of Ewekoro formation of Southern Nigeria sedimentary basin Environ. Earth Sci. 75 (22): 120

Addis, HK and Klik, A (2015). Predicting the spatial distribution of soil erodibility factor using USLE nomograph in an agricultural watershed, Ethiopia. Inter. Soil Wat. Conserv. Res. 3(4): 282-290

Adepoju, K, Adelabu, S and Fashae, O (2019). Vegetation Response to Recent Trends in Climate and Landuse Dynamics in a Typical Humid and Dry Tropical Region under Global Change. $A d v$. Meteorology, 2019: 15-30

African Development Bank (AfDB, 2013). Strategic Environmental and Social Assessment https://www.afdb.org/sites/default/files/documents lenvironmental-and-social-assessments/nigeria agricultural_transformation_agenda_support_pro gram - phase 1 atasp-1 -

_executive_sesa_summary.pdf pp 292013

Aiboni, VU (2001). Characteristics and classification of soils of a representative topographic location in the University of Agriculture, Abeokuta. Asset Series A 1(1): 35-50.

Ajiboye GA, Jaiyeoba JO, Olaniyan JO and Olaiya, AO (2015). Characteristics and suitability of the 
soils of some major cocoa growing areas of Nigeria: Etung lga of Cross River. Agrosearch, 15 (1): 101 $-116$

Ajiboye, GA and Aduloju MO (2013). Properties and available micronutrient status of some soils derived from Abeokuta formation in Nigeria. Arch. Agron. Soil Sci. 59 (10): 1393-1408

Ajiboye, GA, Alabi, KO, Adesodun, JK and Aiboni, VU (2011). Classification and Suitability Evaluation of the soils of a topo sequence at Odeda, Ogun State for the production of rice (Oryza sativa). Nigerian J. Soil Sci. 21(2): 142-155.

Ajiboye, GA, Azeez, JO and Omotunde, AJ (2015a). Potassium forms and quantity-intensity relationships in some wetland soils of Abeokuta, Southwestern Nigeria Arch. Agron. Soil Sci. 61 (10): 1393-1408

Ajiboye, GA, Olaniyan, JO, Bosiako, C, and Oyetunde, OO (2014). Assessment of land use pattern and land form on selected physico-chemical properties of soils developed on basement complexsedimentary transitional zone of South Western Nigeria. Nig. J. Soil Sci. 24: 13-23

Ajiboye, GA, Oyetunji, CA, Mesele, SA and Talbot, J (2019). The role of soil mineralogical characteristics in sustainable soil fertility management: A case study of some tropical alfisols in Nigeria. Comm. Soil Sci. Plant Anal. 50 (3): 333349

Alabi, AA, Akinyemi, OD, Olowofela, JA, Salako, FK, Ajiboye, GA, and Olurin, OT (2017). Temporal variation of ground temperature at depths $2 \mathrm{~cm}$ to $200 \mathrm{~cm}$ in an experimental field in Abeokuta, South-Western, Nigeria. Arabian J. Geosci. 10 (19): 424

Angima, SD, Stott, DE, O’Neill, MK, Ong, CK and AWeesies, G (2003). Soil erosion prediction using RUSLE for central Kenyan highland conditions. Agric. Ecosystems. Environ. 97(1-3): 295-308

Arab, AI, Abubakar, SZ and Idris, UD (2013). Evaluation of Empirical and Nomograph Method of Predicting Erodibility Index for Selected Savannah Soils. Pac. J. Sci. Tech. 14(1):517-523.

Barrena-González, J., Rodrigo-Comino, J., GyasiAgyei, Y., Fernández, M. P. and Cerdà, A.
Applying the RUSLE and ISUM in the Tierra de Barros Vineyards (Extremadura, Spain) to Estimate Soil Mobilisation Rates. Land 2020, 9(3): 93-110

Basile, A, Albrizio, R, Autovino, D, Bonfante, A, De Mascellis, R, Terribile, F, and\& Giorio, PA (2020). Modelling approach to discriminate contributions of soil hydrological properties and slope gradient to water stress in Mediterranean vineyards. Agricultural Water Management, 241: 106338

Bewket W and Teferi, E (2009). Assessment of soil erosion hazard and prioritization for treatment at the watershed level: Case study in the Chemoga watershed, Blue Nile basin, Ethiopia. Land Degradation \& Development, 20 (6): 609-622

Bouyoucos, GJ (1962). Hydrometer Method Improved for Making Particle Size Analyses of Soils1. Agronomy journal, 1962 - Wiley Online Library.

Cassol, EA, Silva, TS, Eltz, FLF, and Levien, R (2018). Soil Erodibility under Natural Rainfall Conditions as the $\mathrm{K}$ Factor of the Universal Soil Loss Equation and Application of the Nomograph for a Subtropical Ultisol. Revista Brasileira de Ciência do Solo, 2018, 42, e0170262

Cooke, H (2020). On the Conservation of Natural Resources, with special reference to the Kalahari in Botswana. Botswana Notes and Records, 1981, 13, 141-143. Retrieved June 17, 2020, from www.jstor.org/stable/40979645

Dada, POO, Adeyanju, OR, Adeosun, OJ and Adewumi JK (2016). Effects of soil physical properties on soil loss due to manual yam harvesting under a sandy loam environment. Inter. Soil. Wat. Conserv. Res. 4(2): 121-125

Dastagir, PB, Vilas, GV and Sakthivel, M (2020). Prioritization of watershed based on soil erosion model: A case study of Noyyal river basin, Tamil Nadu. J. Global Res. 6 (2): 123-133.

Ferreira, V, Panagopaulos, T, Andrade, R, Guerrero, C and Loures, L (2015). Spatial variability of soil properties and soil erodibility in the Alqueva reservoir watershed. Solid Earth, 6: 383-392.

Ganasri, BP and Ramesh, H (2016). Assessment of soil erosion by RUSLE model using remote sensing and GIS - A case study of Nethravathi Basin. Geosci. Frontiers, 7(6): 953-961. 
Gaubi, I, Chaabani, A and Hamza, MH (2017). A GISbased soil erosion prediction Using Revised Universal Soil Loss Equation (RUSLE) (Lebna watershed, Cap Bon, Tunisia), Nat. Haz.86: 219239

Ghosh, S and Guchhait, S (2012). Soil Loss Estimation through USLE and MMF Methods in the Lateritic Tracts of Eastern Plateau Fringe of Rajmahal Traps, India. Ethiop. J Environ. Stud. Manage. 5(4). 13

Greig-Smith, P. Pattern in a derived savanna in Nigeria. Journal of Tropical Ecology, 1991, 7(4): 491-502

Harmonized World Soil Database 1.1 (HWSD, 2009). FAO/IIASA/ISRIC/ISS-CAS/JRC, FAO, Rome, Italy and IIASA, Laxenburg, Austria. 2009, pp. 139.

http://www.fao.org/fileadmin/templates/nr/docum ents/HWSD/HWSD Documentation.pdf

Karan, SK, Ghosh, S, and Samadder, SR (2019). Identification of spatially distributed hotspots for soil loss and erosion potential in mining areas of Upper Damodar Basin - India. CATENA, 182: 104144.

Kassam, AH, van Velthuizen, HT, Fischer GW and Shah, MM (1993). Agro-ecological land resources assessment for agricultural development planning a case study of kenya resources data base and land productivity. Main Report, 1993. Available online at

http://www.fao.org/3/t0737e/T0737E00.htm\#TOC

Krasa, J, Dostal, T, Vrana, K and Plocek, J (2009). Predicting spatial patterns of sediment delivery and impacts of land-use scenarios on sediment transport in Czech catchments. Land Degrad. Develop. 21, (4), 367

Kusumandari, A (2014). Soil Erodibility of Several Types of Green Open Space Areas in Yogyakarta City, Indonesia Procedia Environmental Sciences, 20: $732-736$

Lal, R (2015). Restoring Soil Quality to Mitigate Soil Degradation. Sustainability, 7: 5875-5895.

Lee, GS, Lee, KH (2006). Scaling effect for estimating soil loss in the RUSLE model using remotely sensed geospatial data in Korea. J. Hydrology and Earth System Sci. 3: 135e157.
Morgan, RPC and Nearing M. (Eds) (2016). Handbook of Erosion Modeling. John Wiley \& Sons, Technology \& Engineering. Pp. 608

Morgan, RPC, Quinton, JN, Rickson, RJ (1994). Modelling methodology for soil erosion assessment and soil conversion design: the EUROSEM approach. Outlook on Agriculture, 23, 5-9

Nath, NT and Krishna, BG (2014). Influence of soil texture and total organic matter content on soil hydraulic conductivity of some selected tea growing soils in Dibrugarh district of Assam. Inter. Res. J. Chem. Chem. Sci. 1(1): 002-009.

Omokhafe, K (2017). Social Factors of Derived Savanna in Northern Edo State, Nigeria. Asian J. Adv. Agric. Res. 1(4): 1-4

Oyenuga, VA (1967). Agriculture in Nigeria. Food and Agriculture Organization of the United Nations). FAO, Rome, Italy. 1967, 308 pp.

Renard, KG Foster, GR, Weesies, GA, McCool DK, and Yoder DC (Coords) (1997). Predicting Soil Erosion by Water: A Guide to Conservation Planning with the Revised Universal Soil Loss Equation (RUSLE). Agriculture Handbook 703, pp.413.

Reynolds, WD, Elrick, DE, (2002). Falling head soil core (tank) method. Methods soil Anal., 4: 809-812.

Salako, FK (2007). Temporal variation of rainfall erosivity in southern Nigeria. ASSET Series A, 7(1): 190-202.

Salako, FK (2008). Rainfall variability and kinetic energy in southern Nigeria. Climatic Change, 86: 151-164

Salako, FK, Osiname, O and Akinsanya, O (2006b). Growth and nutrient concentration of upland rice cultivated on marginal lands in Abeokuta. ASSET Series A, 6: 189-203.

Salako, FK, Tian, G, Kirchhof G (2008). Soil chemical properties and crop yields on an eroded Alfisol managed with herbaceous legumes under yammaize rotation. Nig. J. Soil Sci. 18:1-9

Sharda, VN, Juyal, GP and Singh, PN (2002). Hydrologic and sedimentologic behavior of a conservation bench terrace system in a sub-humid 
climate. Transactions of the ASAE, 45(5): 14331441.

Tavares FJ and Tessier, D (2009). Characterization of soil structure and porosity under long-term conventional tillage and no-tillage systems. Revista Brasileira de Ciência do Solo. 33(6): 1837-18441446.

Ufoegbune, GC and Fabiyi, S (2016). Identification of Land areas suitable for Fadama Farming at Federal University of Agriculture, Abeokuta, Nigeria using GIS. J. Appl. Sci. Environ. Manage. 20 (4): 1027 1032

Várallyai, G (2015). Soil, as a multifunctional natural resource. Columella: J. Agricultural and Environmental Sciences, 2 (1)1: 9-19.

Veiga, M, Reinert, DJ, Reichert, JM, and Kaiser, DR (2008). Short and long-term effects of tillage systems and nutrient sources on soil physical properties of a Southern Brazilian Hapludox. Revista Brasileira de Ciência do Solo. 32(4): 14371446.
Vijith, H, Hurmain, A and Dodge-Wan, D (2018). Impacts of land use changes and land cover alteration on soil erosion rates and vulnerability of tropical mountain ranges in Borneo. Remote Sensing Applications: Soc. Environ. 12: 57-69

Wallin, DE (2013). Beryllium-7: The Cinderella of fallout radionuclide sediment tracers? Hydrological Processes, 27(6):830-844

Wischmeier WH and Smith, DD, (1978). Predicting Rainfall Erosion Losses: A Guide to Conservation Planning, Agriculture Handbook 537. Washington, D.C: US, Department of Agriculture, 58p

Yusof, MF, Abdullah, R, Azamathulla, HM, Zakaria, NZ and Ghani. AA (2011). Modified soil erodibility factor, $\mathrm{K}$ for peninsular Malaysia soil series. In: 3rd International Conference on Managing Rivers in the 21st Century: Sustainable Solutions for Global Crisis of Flooding, Pollution and Water Scarcity. 799-808 Rivers 2011 6th - 9th December 2011, Penang, Malaysia. 